\title{
Development dynamics of outsourcing of auxiliary activities among Polish medical entities in the years 2012-2018
}

\author{
Dynamika rozwoju outsourcingu działalności pomocniczej w polskich podmiotach leczniczych \\ w latach 2012-2018
}

\author{
Mariola Borowska, Anna Augustynowicz, Aleksandra Czerw ${ }^{凶}$
}

Warszawski Uniwersytet Medyczny, Zakład Ekonomiki Zdrowia i Prawa Medycznego, ul. Jana Nielubowicza 5, 02-097 Warszawa

Medical University of Warsaw, Department of Health Economics and Medical Law

$\bowtie$ aleksandra.czerw@wum.edu.pl

\begin{abstract}
Introduction: In the face of insufficient resources, healthcare providers are forced to constantly analyse and evaluate the financial economy and, within the economic framework, to rationally reduce the costs of their activities. Outsourcing is one of the ways to rationalise costs in healthcare. It concerns both core and ancillary activities.

The aim of this study was to present the dynamics of outsourcing development of auxiliary activities of medical entities in Poland. Materials and methods: Analysis was based on the results of surveys conducted in 2012, 2014, and 2018. In 2012, 153 medical entities qualified for analysis, 156 in 2014, and 750 in 2018. The number of entities using outsourcing is presented, together with an indication of the type of services covered by outsourcing, reasons for outsourcing, benefits and drawbacks that the entities
\end{abstract}

have noted, including measurement of financial effectiveness of outsourcing, and monitoring of the outsourcing partner.

Results: Medical entities usually outsource waste treatment services, likely due to the difficulty for medical entities to meet the strict requirements set out in the law. The least frequently outsourced service is nutrition, which most likely results from the dissatisfaction of medical entities with the services provided by external companies.

Conclusions: Excessive cost of maintaining employees was a common justification for outsourcing. Financial efficiency is the most desirable effect and the most frequent stimulus for medical entities undertaking various types of activities, including outsourcing in the field of auxiliary activities.

Keywords: outsourcing of ancillary services; financial efficiency; medical entities; cost rationalisation.

\begin{abstract}
ABSTRAKT
Wstęp: Podmioty lecznicze w obliczu niewystarczających środków zmuszane są do stałej analizy i oceny gospodarki finansowej, a w ramach jej prowadzenia do redukcji kosztów swojej działalności zgodnie z zasadą racjonalności. Outsourcing jest jednym ze sposobów racjonalizacji kosztów w ochronie zdrowia. Dotyczy on zarówno działalności podstawowej, jak i pomocniczej. Celem pracy było przedstawienie dynamiki rozwoju outsourcingu w zakresie pomocniczej działalności podmiotów leczniczych.

Materiały i metody: Analiz dokonano na podstawie wyników badania ankietowego przeprowadzonego w 2012, 2014 i 2018 r. W 2012 r. zakwalifikowano do analizy 153 podmioty lecznicze, w 2014 r. - 156, zaś w 2018 r. - 750. W artykule wykazano liczbę podmiotów stosujących outsourcing wraz ze wskazaniem rodzaju usług zlecanych na zewnątrz, jego powodów, korzyści i wad, jakie odnotowano, w tym związanych z efektywnością
\end{abstract}

finansową, a także sposobów monitorowania partnera outsourcingowego.

Wyniki: Podmioty lecznicze najczęściej zlecają na zewnątrz usługę utylizacji odpadów, co zapewne jest związane z trudnością w spełnieniu, określonych w przepisach prawa, surowych wymogów. Najrzadziej zlecaną na zewnątrz usługą jest żywienie, co najprawdopodobniej wynika z niezadowolenia podmiotów leczniczych ze świadczonych przez firmę zewnętrzną usług. Wnioski: Zbyt wysoki koszt utrzymania pracowników, jako uzasadnienie outsourcingu, zapewne jest następstwem wysokich kosztów zatrudnienia na podstawie stosunku pracy. Efektywność finansowa jest najbardziej pożądanym wynikiem i najczęstszym bodźcem prowadzącym do podjęcia różnego rodzaju działań przez podmioty lecznicze, $w$ tym działań outsourcingu w zakresie działalności pomocniczej.

Słowa kluczowe: outsourcing usług pomocniczych; efektywność finansowa; podmioty lecznicze; racjonalizacja kosztów.

\section{INTRODUCTION}

Outsourcing is one of the ways to rationalise costs in health care. It consists of separating various types of activities from the structure of medical entities and then transferring their implementation to external companies [1].
International experience shows that among medical entities outsourcing is most often related to protection of property, cleaning services, and nutrition of patients. More and more medical entities also outsource laboratory tests $[2,3,4]$. 
International literature presents widely varying experiences related to the use of outsourcing in health care in individual countries $[5,6,7,8,9,10,11,12]$. In the Polish literature, outsourcing in health care is presented in the form of a case report, i.e. as a presentation of the type of outsourcing and financial effectiveness in specific, individual therapeutic entities [13]. So far, no wider scientific research has been carried out in Poland in order to determine the number of entities using outsourcing, the type of outsourcing, the dynamics of development of particular types of outsourcing, and its financial effectiveness.

The aim of this study was to present the dynamics of outsourcing development in the scope of auxiliary activities of medical entities in Poland in 2012, 2014, and 2018.

\section{MATERIALS AND METHODS}

The research material consisted of author's questionnaires provided electronically to therapeutic entities selected from the National Register of Medicinal Entities. The survey was conducted in 2012, 2014, and 2018. Basic and ancillary services were examined. In the scope of auxiliary activities, the following services were examined: cleaning, laundry, nutrition, property protection, and waste disposal. The questions concerned the number of entities using outsourcing together with an indication of the type of services outsourced, the reasons for outsourcing by medical entities, the benefits and drawbacks that the entities have noted, including the measurement of financial effectiveness of outsourcing; and monitoring of the outsourcing partner.

In 2012, 153 questionnaires qualified for analysis, 156 in 2014 and 750 in 2018.

The study conducted in 2012 was a pilot study. In 2014, the study was continued. In 2018, the study was carried out for longer and supplemented with basic services. On the basis of the research results, the dynamics of outsourcing development in the scope of auxiliary activities of medical entities was presented.

The analysis examined the number of medical entities using different types of outsourcing for auxiliary services, reasons for outsourcing, benefits resulting from outsourcing including measurement of financial effectiveness, and monitoring of the external companies. The percentage of savings for the healthcare providers achieved by outsourcing compared to the costs of performing the same function before separating was examined. Responses provided by medical entities were analysed by means of statistical tests, such as the Friedman test or the $\chi^{2}$ test. Based on the bimodal distribution, $95 \%$ confidence intervals were prepared and used to compare different values in and between tables.

\section{RESULTS}

In 2012, the survey covered 153 medical entities, $70 \%$ of which were public entities. Less than $50 \%$ of medical entities employed less than 50 employees (measured in terms of the number of medical personnel). In the majority of cases, the treatment entities included in the study operated in towns with populations of up to 20,000 inhabitants. In 2014, the study covered 156 treatment entities, of which about $40 \%$ were public entities and $60 \%$ were private entities. The majority $(\sim 60 \%)$ of respondents were small medical entities employing between 1 and 50 employees (measured in terms of the number of medical personnel). Like in the 2012 study, in the majority of cases, the treatment entities functioned in towns with populations of up to 20,000 inhabitants. In 2018, the study covered 750 medical entities, including 446 public entities (59.5\%) and 296 private entities (39.5\%). Less than $45 \%$ of the medical entities employed less than 50 employees (measured in terms of the number of medical personnel). Again, the majority of treatment entities covered by the study functioned in towns with populations of up to 20,000 inhabitants.

The number of medical entities using outsourcing for auxiliary services was analysed. Table 1 presents the number and percentage of medical entities using outsourcing of selected auxiliary services in 2012, 2014, and 2018.

TABLE 1. Number and percentage of medicinal entities using outsourcing of auxiliary services in 2012, 2014 and 2018

\begin{tabular}{lcccccc}
\multirow{2}{*}{ Parameters } & \multicolumn{2}{c}{2012} & \multicolumn{2}{c}{2014} & \multicolumn{2}{c}{2018} \\
\cline { 2 - 7 } & $\mathbf{n}$ & $\%$ & $\mathbf{n}$ & $\%$ & $\mathbf{n}$ & $\%$ \\
\hline $\begin{array}{l}\text { Maintenance of } \\
\text { cleanliness }\end{array}$ & 40 & 26.14 & 48 & 30.76 & 373 & 49.70 \\
\hline Laundry services & 50 & 32.67 & 81 & 51.92 & 427 & 56.90 \\
\hline Nutrition & 44 & 28.75 & 34 & 21.79 & 303 & 40.40 \\
\hline Asset protection & 72 & 47.05 & 88 & 56.41 & 490 & 65.30 \\
\hline Waste treatment & 141 & 92.81 & 142 & 91.02 & 660 & 88.00 \\
\hline n- number of entities; \%- percentage of sample & & &
\end{tabular}

Based on the $\chi^{2}$ test, it was found that there is a statistically significant difference in the percentage of entities outsourcing cleaning services $\chi^{2}(4)=53.66, p<0.05$, nutrition services $\chi^{2}(4)=44.17, \mathrm{p}<0.05$, and waste treatment services $\chi^{2}(4)=109.32, \mathrm{p}<0.05$, but no statistically significant differences were found for outsourcing laundry services $\chi^{2}(4)=64.69$, $p>0.05$, and property protection services $\chi^{2}(4)=75.35, p>0.05$. In each survey, about $90 \%$ of respondents declared using an external company for waste disposal, it was the most frequently outsourced service. Outsourcing of security services is also becoming more and more popular. In 2012, 47\% of respondents indicated that this service was outsourced to an external company, in $2014-56 \%$ of respondents, in $2018-65 \%$. The least frequently outsourced service is nutrition. In the 2012 survey, $30 \%$ of respondents indicated the outsourcing of feeding services, while in 2014 only $22 \%$. In 2018 , about $40 \%$ of medical entities indicated that they outsource nutrition services. No regularity of the increase or decrease in the percentage of medical entities outsourcing nutrition services was observed.

The reasons for the use of outsourcing of auxiliary activities by therapeutic entities are also presented. In each of the 
three studies, the most common reason was the excessively high cost of living for the entities' own employees and the need to introduce financial savings. The percentage of respondents indicating the aforementioned issues oscillated around $35-40 \%$ of answers. In all three studies, the high a cost of maintaining one's own staff was most frequently indicated as the reason for outsourcing cleaning and property protection services. In the case of waste treatment, the majority of medical entities have never employed staff to carry out this activity. In 2012, 72\% of medical entities indicated such a response, in $2014-74 \%$, and in $2018-76 \%$ of medical entities. The need to introduce financial savings was most often indicated in regards to cleaning and property protection services, and least frequently in regards to waste disposal.

Taking into account the most common reasons why healthcare providers decide to outsource (high cost of maintaining their own staff and the need to introduce financial savings), a study performed in 2018 determined whether healthcare providers managed to achieve the desired financial savings. In each of the surveyed areas of auxiliary activities, financial savings were recorded by $30-45 \%$ of respondents. The average percentage savings estimated by respondents was $20.11 \%$ with a standard deviation of 1.58 . The $95 \%$ confidence interval of the estimated savings lies between $16.98 \%$ and $23.3 \%$. Financial savings were indicated more often in the case of cleaning, laundry services, and property protection, and less frequently in the case of nutrition and waste disposal.

In addition to the possible financial benefits, it was examined whether healthcare providers had gained other benefits from the outsourcing of ancillary activities. Improvement in the quality of services provided in each of the three studies was indicated in relation to cleaning, laundry services, and property protection. In the case of waste disposal, respondents had no comparison, as they had been using an external company in this area since the beginning of their operation. A different situation applies to the outsourcing of feeding services. Table 2 compares the percentage of satisfaction with the nutrition services in the analysed period.

TABLE 2. Percentage satisfaction with the food service in 2012, 2014, and 2018

\begin{tabular}{llllllll} 
& & \multicolumn{2}{c}{2012} & & \multicolumn{2}{c}{2014} & \multicolumn{2}{c}{2018} \\
\cline { 2 - 7 } Parameters & n & $\%$ & n & $\%$ & n & $\%$ \\
\hline
\end{tabular}

Decrease in the level of employee and patient satisfaction related $\begin{array}{llllll}42 & 27.45 & 28 & 17.94 & 93 & 12.40\end{array}$ to meals consumed

$\mathrm{n}$ - number of persons; \% - percentage of sample

All three studies pointed to a decrease in employee and patient satisfaction with food when catering service is outsourced to an external company. Based on the $\chi^{2}$ test, a statistically significant correlation was found, showing a downward trend in satisfaction with the food service when outsourced $\chi^{2}(2)=89.06, p<0.05$. The percentage of respondents who drew attention to this unfavourable phenomenon decreased from $27 \%$ in 2012 to $18 \%$ in 2014 (a decrease of 9 percentage points). In the survey conducted in 2018, this percentage was only $12 \%$ (further decrease, 6 percentage points).

Another issue analysed in the study is the monitoring of the outsourcing partner by therapeutic entities. Table 3 presents the percentage of therapeutic entities monitoring the outsourcing partner. Based on the $\chi^{2}$ test, a statistically significant difference was found in terms of the increase in the percentage of treatment entities that do not monitor the activities of external companies $\chi^{2}(2)=87.98$, the value of $p<0.05$.

TABLE 3. Percentage of medical entities monitoring the outsourcing partner in 2012, 2014, and 2018

\begin{tabular}{lcccccc} 
Monitoring of the & \multicolumn{2}{c}{2012} & \multicolumn{2}{c}{2014} & \multicolumn{2}{c}{2018} \\
\cline { 2 - 7 } outsourcing partner & $\mathrm{n}$ & $\%$ & $\mathrm{n}$ & $\%$ & $\mathrm{n}$ & $\%$ \\
\hline Yes & 107 & 70.00 & 88 & 56.41 & 414 & 55.28 \\
\hline No & 46 & 30.00 & 68 & 43.59 & 336 & 44.72 \\
\hline
\end{tabular}

$\mathrm{n}$ - number of entities; \% - percentage of sample

In each of the three studies, it was checked whether treatment providers monitor the quality and delivery of ancillary services. In the study conducted in 2012, approximately $70 \%$ of medical entities declared that they monitor the activities of outsourcing partners. Lower results were achieved in subsequent years (in $2014-56 \%$ of respondents, in $2018-55 \%$ of respondents). In all three studies, therapeutic entities indicated that the monitoring of waste management was the most frequent, and the least frequent was the monitoring of nutrition. Informal internal control is exercised by a small percentage of medicinal entities. On the other hand, a formalised assessment based on the specificity of the service is indicated by an average of half of the respondents in each of the five areas of auxiliary activities, in each of the three studies. A formalised assessment based on the specific nature of the service was most often carried out for waste treatment services. Such an answer was most often indicated in the surveys conducted in 2014 and 2018.

Another issue analysed is the satisfaction of medical entities with the outsourcing of auxiliary services (Table 4).

Based on Friedman test, it was found that the degree of satisfaction with the auxiliary services provided differed significantly depending on the type of service, $\chi^{2}(4)=103.79$, $p<0.001$. Statistically significant differences were found for

TABLE 4. Satisfaction with auxiliary services provided by external companies in the analysed period

\begin{tabular}{cccccc}
\multirow{2}{*}{$\begin{array}{c}\text { Support } \\
\text { services }\end{array}$} & & Yes & Nopartially & In part & $\begin{array}{c}\text { Not } \\
\text { applicable }\end{array}$ \\
\hline \multirow{2}{*}{2012} & $\mathrm{n}$ & 131 & 4 & 15 & 3 \\
\cline { 2 - 6 } & $\%$ & 85.60 & 2.64 & 9.80 & 1.96 \\
\hline \multirow{2}{*}{2014} & $\mathrm{n}$ & 104 & 7 & 26 & 19 \\
\cline { 2 - 6 } 2018 & $\mathrm{n}$ & 46.22 & 4.48 & 16.60 & 12.17 \\
\cline { 2 - 6 } & $\%$ & 62.40 & 0.80 & 6.94 & 224 \\
\hline
\end{tabular}

$\mathrm{n}$ - number of entities; \% - percentage of sample 
most of the analysed comparisons, except for the comparison of the degree of satisfaction with laundry and cleaning services and the comparison of the degree of satisfaction with waste treatment and property protection. The results of the conducted research indicate a decrease in the satisfaction of medical entities with the provided services - from $86 \%$ in 2012 to $67 \%$ in 2014. An increase is observed in partial satisfaction with the services provided: from $10 \%$ in 2012 to $16 \%$ in 2014 (an increase of 6 percentage points). In 2012, among the respondents who indicated partial satisfaction with the services provided by an outsourcing partner, the most frequent were answers concerning waste disposal, property protection, and laundry services. In 2014, the services the respondents are satisfied with are waste management and property protection. In the survey conducted in 2018, the highest degree of satisfaction was found for waste disposal $(80 \%)$ and property protection $(60 \%)$, lower in the case of laundry and cleaning services and the lowest in the case of food services (25\%).

\section{DISCUSSION}

As part of the analysis conducted, it was found that over the years under study, most of the medical entities outsource waste disposal services. The number of affirmative answers remained at a similar level, about $90 \%$ of respondents. Perhaps the high percentage of medical entities outsourcing this service is a consequence of the detailed requirements laid down in the applicable legal regulations. These issues are regulated by the Ordinance of the Minister of Health of 5 October 2017 on the detailed method of handling medical waste (Journal of Laws 2017, item II.1.1, as amended), and by the Ordinance of the Minister of Health of 5 October 2017 on the detailed method of handling medical waste (Journal of Laws 2017, item II.1.2). The regulations define the detailed manner of handling medical waste, including: handling of medical waste generated as a result of health services provided at the place of call, the procedure for collecting medical waste in containers or bags at the place of its generation and for preliminary storage of medical waste in facilities where health services are provided or scientific research and experiments in medicine are conducted, and the conditions of internal transport, hereinafter referred to as "internal transport of medical waste" [14]. It may be difficult for healthcare providers to comply with strict legal requirements. It is likely that meeting them would require significant financial outlay, which may be difficult for medical entities to allocate [15]. Therefore, the most popular form of outsourcing is probably in the area of waste disposal. This is not only a financially effective solution, but also seems to be obligatory in many cases.

In the 2012 survey, $30 \%$ of respondents indicated the outsourcing of feeding services. In 2014, there was a regression with only $22 \%$ of respondents responding positively. Then, in 2018 , about $40 \%$ of medical entities indicated that they outsource nutrition services. However, this still remains the least outsourced service. This is probably related to the lack of satisfaction with food outsourcing, as indicated by therapeutic entities in all of the three studies. Nutrition is an activity that is important to patients and is relatively easy to verify. A properly selected diet, with good variety, quality, and appearance of served meals directly affects the quality of care perceived by patients. It is worth noting that in 2012 almost $70 \%$ of medical entities declared that they do not have a kitchen and buy ready meals delivered by a catering company. In the following years, this percentage increased. Meals are delivered to the medical entity wholesale, then distributed at the branches. In this situation, there is no possibility for meticulous quality control of meals. There are also delays or shortages in ordered meals. A similar relationship has been observed in studies on the outsourcing activities of medical entities in Italy. Less than $50 \%$ of public health service providers took part in that survey. It was established that outsourcing most often concerns auxiliary functions, including feeding. Very often institutions have too high expectations, which are not possible to achieve in a short period of time. As a result, the assessment of outsourcing was positive but not entirely satisfactory. Attention was drawn to important relations with service providers and proper preparation of the therapeutic entity before signing the outsourcing contract. This process should be preceded by a thorough analysis of the service providers available on the market, including the quality of their services and prices, as well as a specification of the requirements to be met by the potential provider. By doing this, the therapeutic entity can construct the contract in such a way as to be able to effectively control the external company, which will result in high quality and satisfaction with the cooperation $[7,8,9]$.

It was found that the most common reasons for outsourcing support services are excessively high maintenance costs and the need for financial savings. It cannot be ruled out that the high a cost of living as a cause of outsourcing is a consequence of the high costs of employing employees. In addition, the employer is obliged to calculate and pay social security contributions and personal income tax. In Poland, in the last decade, the so-called self-employment has been particularly popular. This means that employees register as a one-man, non-agricultural business activity and, as persons conducting business activity, they become an outsourcing partner as an external company or conclude a contract with an external company as an outsourcing partner. As a consequence, social security contributions and personal income tax are borne by the self-employed persons. Without describing here the advantages and disadvantages of self-employment itself, it should be pointed out that it is a cheaper solution than employment based on a regular employment relationship.

In relation to the need to seek financial savings as a reason for outsourcing auxiliary activities, it should be stressed that, in the era of the often-raised argument about the need to rationalise the financial management of therapeutic entities, financial efficiency is the most desirable effect and the most frequent stimulus for therapeutic entities to undertake various actions [16]. The results of studies conducted in 2012 and 2014 indicate that medical entities do achieve savings 
in this respect. A study carried out in 2018 specifies the values of these savings. In each of the surveyed areas of auxiliary activities, financial savings were recorded by $30-45 \%$ of respondents. The average value of the percentage savings estimated by the respondents was $20.11 \%$. Financial savings were indicated more often in the case of cleaning, laundry services, and property protection, and less frequently in the case of feeding and waste disposal. In the case of waste disposal, this is due to the fact that medical entities have very often never employed their own staff, so they do not have a reference point to estimate the potential savings resulting from the outsourcing of this function. An example demonstrating the positive aspects of outsourcing in relation to financial efficiency is the Independent Public Clinical Hospital No. 2 of the Pomeranian Medical University in Szczecin (SPSK nr 2 PUM). The hospital widely uses outsourcing for many services, mainly in the scope of auxiliary and basic functions. A detailed analysis was carried out of the waste disposal and transport services. The analysed medical waste treatment services were provided on the basis of contracts with a significant financial benefit for the hospital. Collected data allow us to state that SPSK nr 2 PUM may be a good example for other hospitals planning to use or improve outsourcing as a useful and increasingly popular method of restructuring or developing their company. The key to the success of this outsourcing activity was the detailed definition of the needs and expectations of the hospital at the stage of specification of the public procurement conditions. As a result, the outsourcing partner performs the outsourced services much better than the organizational units of the hospital [17].

A worrying phenomenon is the observed decrease in the percentage of medical entities monitoring their outsourcing partners. This means that some healthcare providers do not have a reliable knowledge of the quality of services provided by external providers. The decrease in the percentage of entities monitoring outsourcing partners may be a consequence of marginalisation of the quality of auxiliary services by medical entities. Such a state of affairs may also result from a lack of knowledge of the therapeutic subject. Since the healthcare provider is legally and de facto morally responsible to the patient for the quality of services provided, it should not only possess the tools to assess this quality, but also make use of them. Any civil law contract entered into with an external company should include provisions concerning the principles of monitoring and control [18]. In a study on outsourcing among medical entities in Italy, a correlation was observed - when monitoring of an outsourcing partner is performed, based on specific requirements included in the outsourcing agreement, the quality of services provided is higher, and thus the therapeutic entity's satisfaction with the cooperation is also high [7, 8, 9].

Medical entities most often monitor the waste treatment service. This may be related to the legal regulations that outline in a detailed manner the handling of medical waste generated at the place of its production (Regulation of the Minister of Health of 5 October 2017 on the detailed handling of medical waste). This makes it easier for healthcare providers to refer to specific provisions in an outsourcing contract and then evaluate an external company according to these guidelines.

\section{CONCLUSIONS}

1. Waste management outsourcing is growing in popularity, which is probably related to the difficulty for medical entities to meet the strict requirements set out in the law on this issue.

2. The least frequently outsourced service is nutrition, which most likely results from the dissatisfaction of medical entities with the services provided by external companies. The excessively high cost of maintaining employees as a justification for outsourcing is probably a consequence of high costs of employing employees under employment contracts. As a result, so-called self-employment is becoming more and more popular.

3. Financial efficiency is the most desirable effect and the most frequent stimulus for medical entities to undertake various types of activities, including outsourcing of auxiliary activities.

4. The decreasing percentage of treatment providers monitoring their outsourcing partners may be a consequence of medical providers' marginalisation of the quality of ancillary services. It may also result from a lack of clarification in regards to monitoring and control rules in the agreement with the outsourcing partner.

\section{REFERENCES}

1. Marcinkowska E. Outsourcing w zarządzaniu szpitalem publicznym. Warszawa: ABC a Wolters Kluwer; 2011.

2. Kister A. Działania outsourcingowe szpitali - przegląd badań. Prace Naukowe Uniwersytetu Ekonomicznego we Wrocławiu 2017;471:188-93.

3. Kautsch M, Ponikło W, Stylo W. Rozważania o outsourcingu. Zdrowie i Zarządzanie 2002;1:17-23.

4. Klich J. Outsourcing jako alternatywa dla klasycznego podejścia do zarządzania zasobami organizacji. In: Kautsch M, editor. Zarządzanie w opiece zdrowotnej. Nowe wyzwania. 2nd ed. Warszawa: Wolters Kluwer; 2015. p. 366.

5. Padman DR, Hamer R, Schwartz S. Determinants if information technology outsourcing among health maintenance organizations. Health Care Management Science 2001;4(3),229-39.

6. Roberts V. Managing strategic outsourcing in the healthcare industry. J Healthcare Management 2001;46(4):239-49.

7. Macinati SM. Outsourcing in the Italian National Health Service: findings from a national survey. Int J Health Planning Management 2008;23(1):2136

8. Young S. Outsourcing in public health: a case study of contract failure and its aftermath. J Health Organization Management 2008;22(5):446-64.

9. Young S. Health Outsourcing/Backsourcing - Case studies in the Australian and Italian health sector. Public Management Rev 2012;14(6):27-34.

10. Socrates J, Moschuris M, Kondylis M. Outsourcing in public hospitals: a Greek perspective. J Health Organization Management 2006;20(1):4-14.

11. Lorencea D, Spink A. Healthcare information systems outsourcing. Int J Information Management 2004;24(2):131-45.

12. Lacity M, Fitzgerald G. Information technology outsourcing in Europe and the USA: Assessment issues. Int J Information Management, 1995;15(5):333-51.

13. Lewandowska H. Outsourcing. Model zarządzania w podmiotach sektora ochrony zdrowia. Warszawa: Wydawnictwo Difin; 2010. p. 200-19. 
14. Rozporządzenie Ministra Zdrowia z dnia 5 października 2017 r. w sprawie szczegółowego sposobu postępowania z odpadami medycznymi (DzU z 2017 r., poz. 1975).

15. Trocki M, editor. Nowoczesne zarządzanie w opiece zdrowotnej. Instrumenty zarządzania zakładami opieki zdrowotnej. Warszawa: IPIS; 2002.

16. Restrukturyzacja wybranych samodzielnych publicznych zakładów opieki zdrowotnej korzystających z pomocy ze środków publicznych.
Raport NIK; 2016. https://www.nik.gov.pl/plik/id,11697,vp,14057 (15.11.2018)

17. Kotlęga D, Nowacki P, Lewiński D. Outsourcing - teoria i zastosowanie w Szpitalu Klinicznym w Szczecinie na przykładzie usług transportu i utylizacji odpadów medycznych. Szczecin: Katedra i Klinika Neurologii Pomorskiego Uniwersytetu Medycznego w Szczecinie; 2014.

18. Trocki M. Outsourcing. Metoda restrukturyzacji działalności gospodarczej. Warszawa: Polskie Wydawnictwo Ekonomiczne; 2001. 